\title{
Stability Analysis of the Entry in a New Mining Approach Influenced by Roof Fracture Position
}

\author{
Jun Yang ${ }^{1,+}$, Hongyu Wang ${ }^{1,2,+}$, Yajun Wang ${ }^{1,3, *}$, Binhui Liu ${ }^{1,2}$, Shilin Hou ${ }^{1,2}$ and Yu Cheng ${ }^{1,2}$ \\ 1 State Key Laboratory for Geomechanics \& Deep Underground Engineering, China University \\ of Mining \& Technology, Beijing 100083, China; yjlr@163.com (J.Y.); wanghongyu0812@163.com (H.W.); \\ cumtb.lbh@gmail.com (B.L.); hslin1993@163.com (S.H.); yxy5211437@163.com (Y.C.) \\ 2 School of Mechanics and Civil Engineering, China University of Mining \& Technology, Beijing 100083, China \\ 3 Department of Geotechnical Engineering, Tongji University, Shanghai 200092, China \\ * Correspondence: wangyj@tongji.edu.cn; Tel.: +86-138-1157-8707 \\ + These authors contributed equally to this work.
}

Received: 21 October 2019; Accepted: 4 November 2019; Published: 12 November 2019

check for updates

\begin{abstract}
Non-coal pillar mining with roadway formed automatically (RFANM) is a new mining approach, which demonstrates revolutionary significance because it does not require making roadway before mining and coal pillar retaining. In order to explore the stability of the surrounding rock structure in RFANM, the deformation of the surrounding rock was theoretically analyzed and simulated based on three different fracture positions of the main roof. It was concluded that reasonable control of temporary support strength in roadway is of great importance to control the deformation of the entry. The deformation process of surrounding rock under different fracture positions in RFANM was simulated by using the Universal Discrete Element Code (UDEC). The results of the numerical simulation showed that the main roof was fractured at the solid coal side or gob side; the deformation of the roadway was small. The fracture condition of the main roof at the gob side required a higher effect of roof slitting or temporary support from the roadway. Through drilling and peeping at the retained roadway, it was judged that the main roof was broken inside the coal wall. Field monitoring results revealed that the deformation of the roadway can be effectively controlled.
\end{abstract}

Keywords: pressure release by roof cutting; non-coal pillar mining with roadway formed automatically (RFANM); roof fracture; surrounding rock deformation; entry stability

\section{Introduction}

Longwall mining is the most common underground mining method in the world [1-3]. With the reduction of coal resources, there are problems in traditional underground coal mining, such as unaffordable driving costs, large surface disturbances, low coal-extraction rates, and the frequent occurrence of safety accidents. Such issues have also been addressed in the literature [4-7]. Following the development path of environment-friendly, safe, high-efficient, non-pillar mining technology, it has been widely used in coal mining. Gob-side entry retaining is a common practice of non-pillar mining in mine shafts, which significantly improves the coal recovery rate, reduces the roadway excavation, allows for the Y-type ventilation on the mining face, and addresses the gas accumulation at the corners of the working surface [8-10].

However, the gob-side entry retaining introduces various drawbacks as a result of coal (rock) pillar retaining, such as stress concentration in the surrounding rock and high risk of gas explosion in the gob zone. Non-coal pillar mining with roadway formed automatically (RFANM) is a new mining technology with no request required for excavating roadways in advance and with coal retaining pillar, 
which avoids various hazards as a result of coal (rock) pillar retaining and allows for safe and efficient coal production [11,12].

The main roof breaks in the form of blocks into the gob zone. This breaking process is affected by factors such as the effect of the roof pre-cracking slit and the strength of the roadway support; there may be multiple occasional breaks in the main roof. Depending upon the locations of the fractures, the extent and severity of the rotation and subsidence of key rock blocks are different, which has a great influence on the stability of roadway.

In order to study the main roof fracture law, a significant amount of research has been conducted on the main roof fracture law and the characteristics of rock pressure appearing during post mining. Literature presents many beneficial results, such as the establishment of pressure arches, articulated rock beams, rock transfer beams, and other structural systems $[13,14]$. The theoretical characteristics of the main roof fracture structure were also explored. Han et al. [15] obtained the given deformation equation of roof and the balance judgment of block fracture on the basis of understanding the stress environment of gob-side entry retaining. The optimum cantilever length is put forward by comparing the roof structure characteristics under six different cantilever lengths and the stress and deformation law of surrounding rock. Li et al. [16] found that by cutting the roof rock in the optimum position, the filling wall can be maintained in a stable state. That study provides theoretical research for the stabilization of the infilling walls and proves the importance of pre-cracked roof rock in an ideal location. Luan et al. [17] found that the rotation and subsidence of key roof block B led to severe deformation of roadway. The proposed roadway stability-control technology can effectively resist the serious deformation of the roadway.

However, most of the existing research focuses on the coal pillar mining and gob-side entry retaining by backfilling. Since RFANM changes the stress transmission of the roof through directional cutting technology of the roof, RFANM has different roof breaking characteristics and strata behaviors, as opposed to conventional gob-side entry retaining.

Although RFANM technology has been successfully applied in more than 20 mines, such as Tashan Mine, Dianping Mine, Halagou Mine, and Jinfeng Mine [18-22], there is a lack of research on the locations of main roof fractures. Thus, based on different fracture structures existing in the main roof of RFANM, this work examines the stress states of the key block at the solid coal side, above the roadway and at the gob side by proposing three theoretical fracture site models for the main roof of RFANM, which was set in in the S1201-II mining face of Ningtiaota Coal Mine of Shaanxi Coal Group. The formula of temporary support strength in roadway was deduced by controlling the constant supporting force of gangue. The results of this study may be deemed useful for the selection of supporting equipment and the optimization of entry retaining craft.

\section{Non-Local Pillar with Roadway Formed Automatically}

RFANM is a new coal-mining technology. It changed the mining face and roadway layout, process and equipment of conventional coal pillar mining, and gob-side entry retaining significantly [23]. The coal-mining machine cuts a roadway space beyond the scraper while cutting; then, that is retained for the next mining face using auxiliary technologies, achieving the end of cancelling the roadway driving on the mining face and the coal pillars in the mining face section, which heralds revolutionary significance for the safe and efficient production of coal mines. Its roadway layout is shown in Figure 1. 


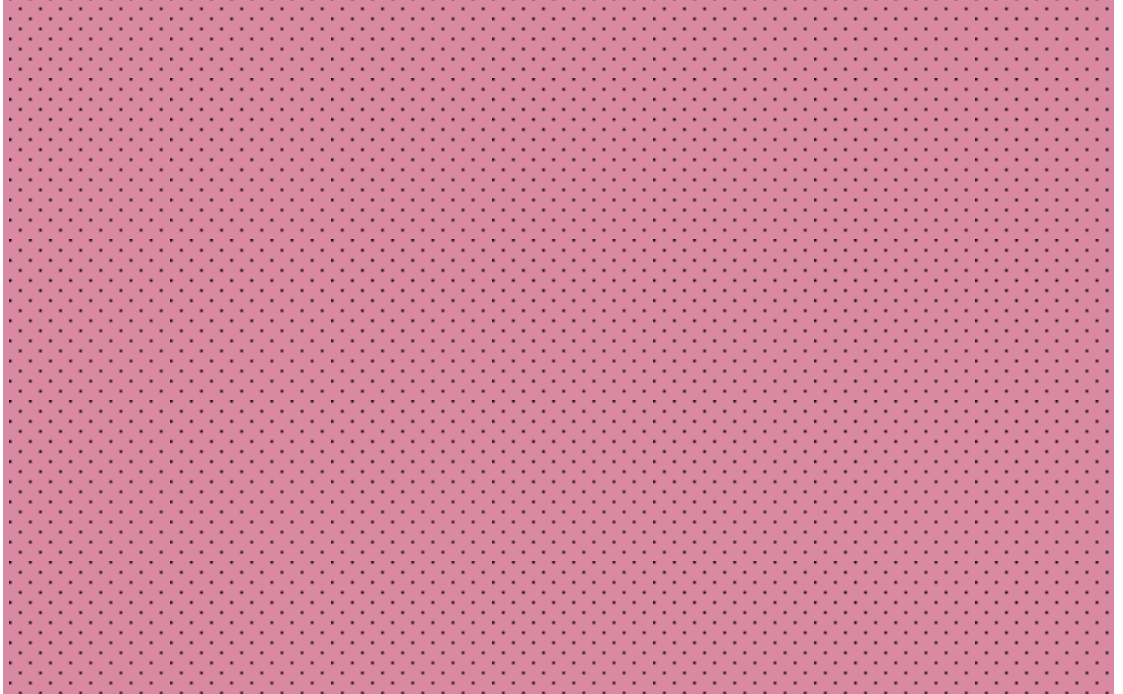

Figure 1. Layout method of roadway in self-forming lane without coal pillar.

The sections orthogonal to the mining direction shown in Figure 2 show that the technological process of the RFANM technique can be divided into the following steps: First, in working-face mining, the shearer cuts the coal while leaving the roadway space and forms the arc roadway wall on the side of the coal wall. Then, the roof of retained roadway is supported by constant resistance and large-deformation anchor cable [24]. In the predefined position above the slit drill, the roof is sliced by the bidirectional, energy-concentrated tension-blasting method, which cuts off the stress transfer between the gob and the roadway roof. The gob roof is automatically caved along the slit face under the action of mine pressure. At the same time, the fallen gangue fills the gob. A gravel gang is formed on the side of the gob under the action of roof-cutting support, U-shaped steel, and other gangue support constructions. Using the RFANM method, non-pillar mining without advancement is successfully implemented.
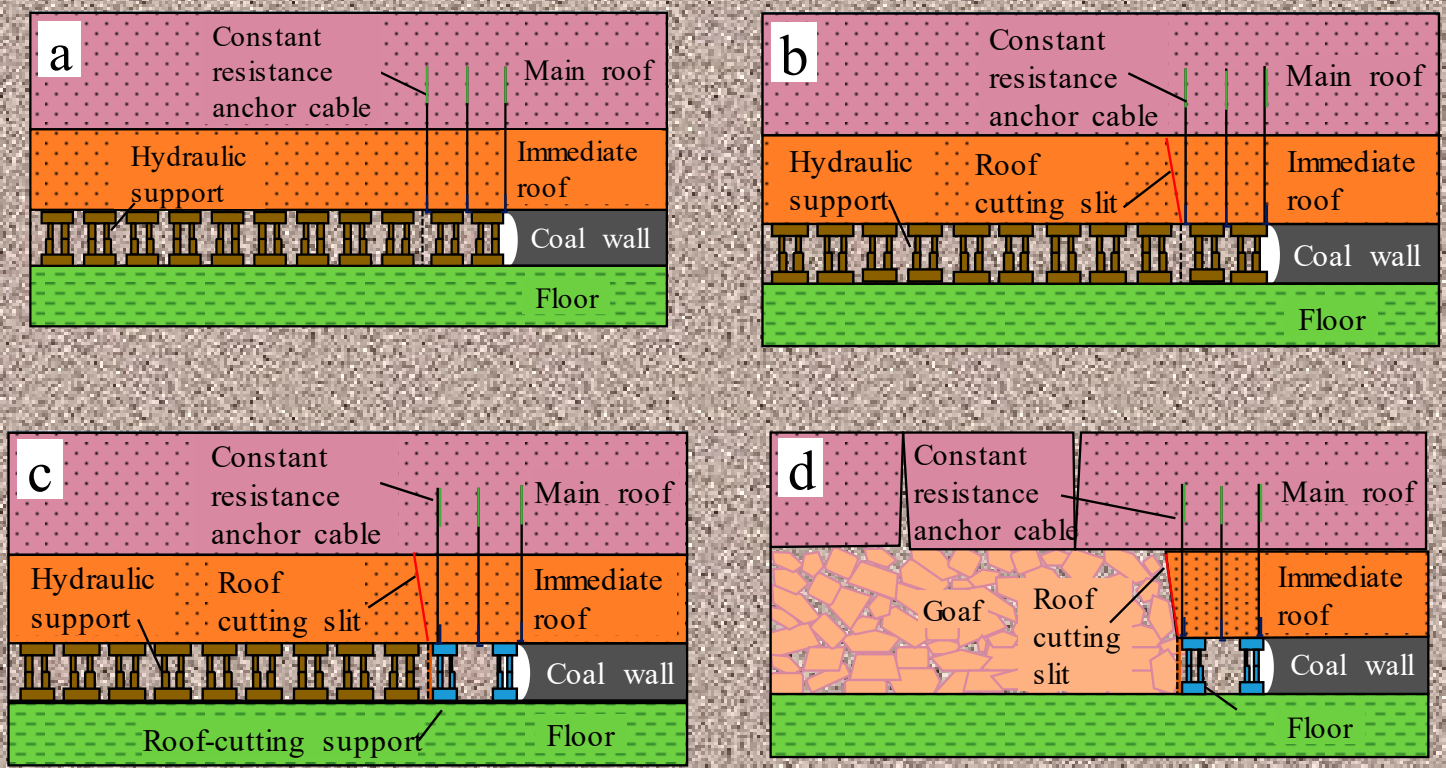

Figure 2. Process flow of non-coal pillar mining with roadway formed automatically (RFANM). (a) Constant resistance anchor support. (b) Roof pre-cracking slot. (c) Roadway-side gangue support. (d) Gob caving. 


\section{Theoretical Models for Different Fracture Sites on the Main Roof}

\subsection{Deformation Characteristics of Roof Strata}

With the advance of the working face and progressive placement of the hydraulic support accordingly, the roof strata lose their supporting capability, and the immediate roof collapses irregularly, leading to volume expansions, and therefore, filling up of the gob zone $[25,26]$. As the directional cutting is performed on the roadway roof where stress transfers between the roadway roof and the immediate gob roof, and a portion of the main roof was cut off, all rocks in the vicinity of the cutting range would cave down. Roof cutting forces the roadway roof to form a short beam structure, which is considered the "equivalent immediate roof" here.

As the working face continues to advance, when the hanging length of the main roof increases to the limit, the main roof breaks and sinks, resulting in periodic rock pressure appearance [27]. The gob-side main roof brakes into block A, B, and C, which engage with each other to form the masonry beam structure. Block $B$ revolves and sinks; the end stretching to the gob side was the earliest to contact the gangue, tending to stabilize as the gangue is gradually compacted; therefore, forming a temporarily-balanced rock beam.

After the rock mass forms by the fracture of the main roof stabilizing, a number of rock groups in the overlying strata begin to separate, break, rotate, and cave down. In this stage, the roadway deformation is characterized by parallel subsidence. In the stable section of the roadway which lags behind a certain distance of the working face, the roof-cutting support in the roadway can be retracted and recycled.

\subsection{Theoretical Model for Fracture of the Main Roof}

During the roof displacement, the stage of the main roof fracture and the sag is the most intense stage of the roof displacement. Therefore, the theoretical model for fracture of the main roof in RFANM was established with reference to the roof motion in this stage. There are three possible fracture sites for the main roof in RFANM: solid coal side, above the roadway, and gob side.

According to the principle of RFANM and the characteristics of roof motion, the following assumptions of the theoretical model for fracture of the main roof in RFANM were made: (1) The roadway roof rotates and settles around the critical site of the solid, coal-side elastoplastic zone as a rotating axis; (2) the deformation range of key blocks is small, and the weights of strata which cannot form a stable masonry structure above the main roof act uniformly on the key blocks; (3) all roofs in the gob-side cutting range will cave; the supporting force against key blocks is uniformly loaded. (4) Because the angle between the blasting slit angle of the roof and the vertical direction is usually small, the influence of the angle of the slit on the force of the key block is negligible; (5) the curved lane is approximately as a straight lane; (6) the filling effect of gangues is ideal. After the main roof breaks, the rotating angle of block B is approximately zero, so that the horizontal thrust between blocks is negligible. (7) The horizontal shear stress between rock strata is negligible.

\subsubsection{Coal-Side Fracture of the Main Roof}

When the strength of temporary support for a roadway is insufficient or the support is provided late, the main roof breaks at the site with a length of $x_{0}$ from the solid coal elastoplastic zone of the roadway. One end of the key block B was extended beyond the solid coal side, and the other end was controlled by the gangue support in the gob and temporary support in the roadway. The free-body diagram analysis for the case of fracture of the main roof at the solid coal side was proposed, as shown in Figure 3. 


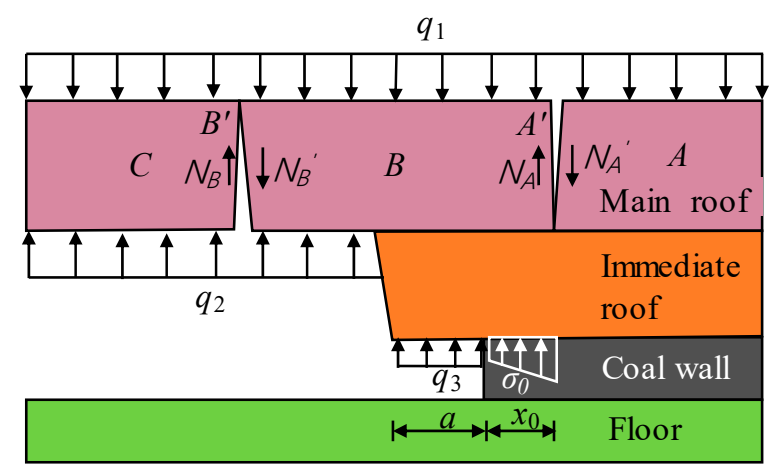

Figure 3. Layout method of a roadway in the self-forming lane without a coal pillar, where $q_{1}$ is the mass of the main roof and the average load of its overlying strata in $\mathrm{kN} / \mathrm{m} ; q_{2}$ is the average load of caved gangues applied on the main roof in $\mathrm{kN} / \mathrm{m} ; q_{2}$ is the average load of temporary support in the roadway in $\mathrm{kN} / \mathrm{m}$; $a$ is the width of the roadway in $\mathrm{m}$; and $\mathrm{N}_{\mathrm{B}}$ and $\mathrm{N}_{\mathrm{A}}$ are the shear forces in $\mathrm{kN}$ imposed by the adjacent rock masses blocks $\mathrm{C}$ and $\mathrm{B}$.

The equations for the width of the solid, coal-side stress limit equilibrium zone, $x_{0}$, and the supporting force of the coal body against the roof, $\sigma_{0},[28]$ are given by Equation (1):

$$
\begin{gathered}
x_{0}=\frac{\lambda \mathrm{A}}{2 \tan \varphi} \ln \left(\frac{k \gamma H+\frac{c}{\tan \varphi}}{\frac{c}{\tan \varphi}+\frac{P}{\lambda}}\right), \\
\sigma_{0}=\left(\frac{c}{\tan \varphi}+\frac{P}{\lambda}\right) e^{\frac{2 x \tan \varphi}{\lambda \mathrm{A}}}-\frac{c}{\tan \varphi},
\end{gathered}
$$

where $\mathrm{A}$ is the thickness of the coal seam in $\mathrm{m} ; \lambda$ is the lateral pressure coefficient; $c$, is the interfacial cohesion between the boundary of coal seam and the roof and floor strata in $\mathrm{MPa}$, and $\varphi$ is the internal friction angle in deg; $k$ is the stress concentration factor; $\gamma$ is the average bulk density of the overlying strata in $\mathrm{kN} / \mathrm{m}^{3} ; H$ is the buried depth of the roadway in $\mathrm{m}$; and $P$ is solid coal support strength in MPa.

In the process of periodic roof collapse, the roof of a gob is in the state of three-points fixed and one-point free. The equation for the fracture length of key blocks is:

$$
L_{i}=l\left(-\frac{l}{S}+\sqrt{\frac{l^{2}}{S^{2}}+\frac{3}{2}}\right),
$$

where $S$ is the length of the mining face and $l$ is the periodic weighting length.

According to Figure 3, blocks $\mathrm{B}$ and $\mathrm{C}$ were isolated using a static balance method for stress analysis. The simplified force equilibrium of key blocks is shown in Figure 4. $\sum F_{y}$ is the resultant force in the Y-axis direction of the key block and $\sum F_{y}=0$ in the equilibrium state. $\sum M_{A^{\prime}}$ is the total bending moment of key block $\mathrm{B}$ at point $A^{\prime}$ and $\sum M_{B^{\prime}}$ is the total bending moment of key block $\mathrm{C}$ at point $B^{\prime}$. 


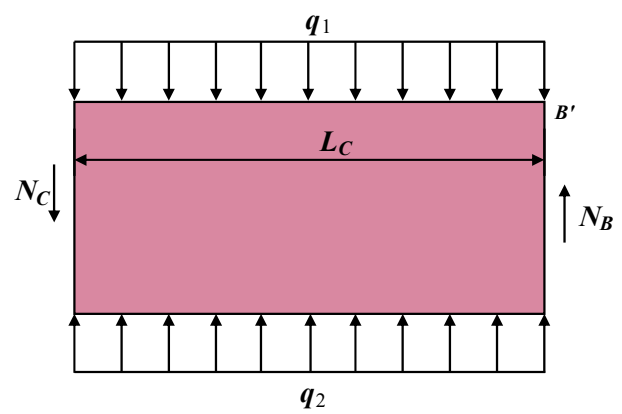

(a) Stress of key block C

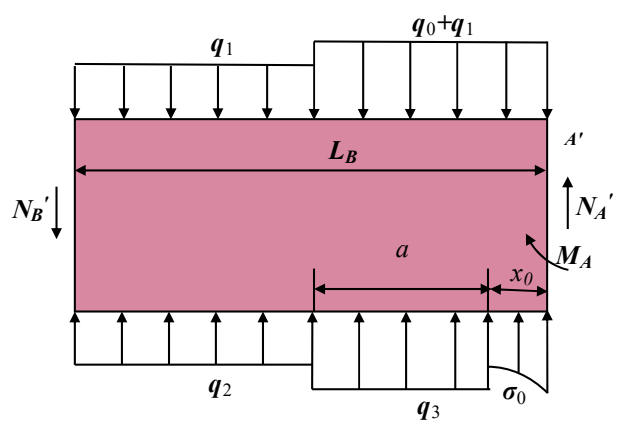

(b) Stress of key block B

Figure 4. Simplified free-body diagram of key rock blocks.

For block $\mathrm{C}$, as $\sum F_{y}=0$, we get

$$
q_{1} L_{C}+N_{C}-N_{B}-q_{2} L_{C}=0 .
$$

As $\sum M_{B^{\prime}}=0$, we get

$$
q_{1} L_{C}^{2} / 2+N_{C} L_{C}-q_{2} L_{C}^{2} / 2=0 .
$$

Simultaneously with Equations (4) and (5), we get

$$
\begin{aligned}
& N_{\mathrm{B}}=\left(q_{1}-q_{2}\right) L_{\mathrm{C}} / 2, \\
& N_{\mathrm{C}}=\left(q_{2}-q_{1}\right) L_{\mathrm{C}} / 2 .
\end{aligned}
$$

For block $\mathrm{B}$, as $\sum F_{y}=0, \sum M_{A^{\prime}}=0$, then

$$
q_{0}\left(a+x_{0}\right)+q_{1} L_{B}+N_{B}{ }^{\prime}-N_{A}-q_{2}\left(L_{B}-a-x_{0}\right)-a q_{3}-\int_{0}^{x_{0}} \sigma_{0} d_{x}=0,
$$

and

$$
\begin{aligned}
& q_{0}\left(a+x_{0}\right)^{2} / 2+q_{1} L_{B}{ }^{2} / 2+N_{B}{ }^{\prime} L_{B}-q_{2}\left(L_{B}-a-x_{0}\right)^{2} / 2- \\
& P_{1}\left(a+2 x_{0}\right) / 2-\int_{0}^{x_{0}} \sigma\left(x_{0}-x\right) d_{x}-M_{A}=0
\end{aligned}
$$

where $q_{0}$ is the average load of the immediate roof, in $\mathrm{kN} / \mathrm{m}$; and $M_{A}$ is the residual bending moment of key block, in $\mathrm{kN} \cdot \mathrm{m}$. And as $P_{1}=q_{3} \times a$, the temporary support strength in the roadway can be obtained by combining Equations (6)-(9).

$$
\begin{gathered}
P_{1}=\left[q_{0}\left(a+x_{0}\right)^{2}+q_{1} L_{B}^{2}+\left(q_{1}-q_{2}\right) L_{B} L_{C}-q_{2}\left(L_{B}-a-x_{0}\right)^{2}-\right. \\
\left.2 M_{A}-2 \int_{0}^{x_{0}} \sigma_{0}\left(x_{0}-x\right) d_{x}\right] /\left(a+2 x_{0}\right) .
\end{gathered}
$$

\subsubsection{Fracture Analysis of the Main Roof above the Roadway}

When the main roof above the roadway is caved in, so block B is supported by the roadway support body and the gob gangue, the roof motion has the most obvious influence on the roadway deformation. When the crack development of the roadway roof is high or the temporary support in the roadway is provided late, the fracture site of the main roof appears above the roadway. Based on those assumptions, the theoretical calculation model for the fracture above the roadway of the main roof in RFANM was established, as shown in Figure 5. 


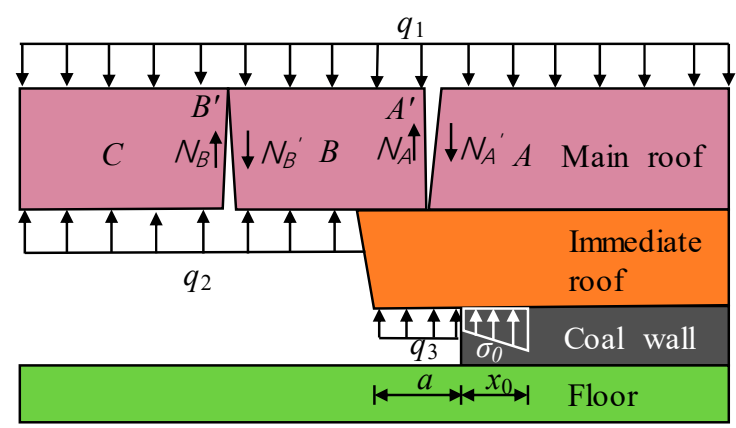

Figure 5. Theoretical model of fracture above a roadway.

The stress analysis of blocks B and C was performed using the static balance method. The stress on block $C$ was the same as that under the gob-side fracture condition. Free body diagram of block $B$ is presented in Figure 6.

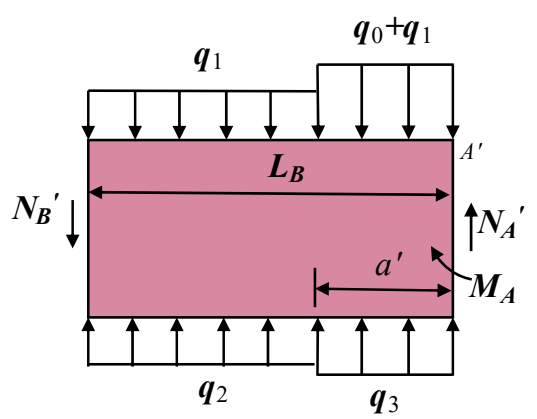

Figure 6. Free body diagram of key block B.

As $\sum M_{A^{\prime}}=0$, then

$$
q_{0} a^{\prime 2} / 2+q_{1} L_{\mathrm{B}}^{2} / 2+N_{B}{ }^{\prime} L_{\mathrm{B}}-q_{2}\left(L_{\mathrm{B}}^{2}-a^{\prime 2}\right) / 2-P_{2} a^{\prime} / 2-M_{A}=0,
$$

where $a^{\prime}$ is the distance from the fracture site of the roof to the edge of the gob-side roadway, in $\mathrm{m}$. Simultaneously with Equations (6), (7), and (11), the temporary support strength in the roadway can be obtained.

$$
P_{2}=\left[q_{0} a^{2}+q_{1} L_{B}^{2}+\left(q_{1}-q_{2}\right) L_{B} L_{C}-q_{2}\left(L_{B}^{2}-a^{\prime 2}\right)-2 M_{A}\right] / a^{\prime} .
$$

\subsubsection{Fracture Analysis of the Main Roof at the Gob Side}

When the theoretical properties of the equivalent immediate roof manifest sufficient stand-up time or the temporary support strength in the roadway was large, the main roof broke along the slotting line. Under this fracture circumstance, key block B was stabilized with the gangue support. The length of the cantilever length above the roadway was less. The stability of the roadway formed was provided by the supporting force of solid coal and the support in the roadway. The theoretical model for the main roof fractures at the gob side was obtained, as shown in Figure 7. The simplified force equilibrium of key blocks A is shown in Figure 8. 


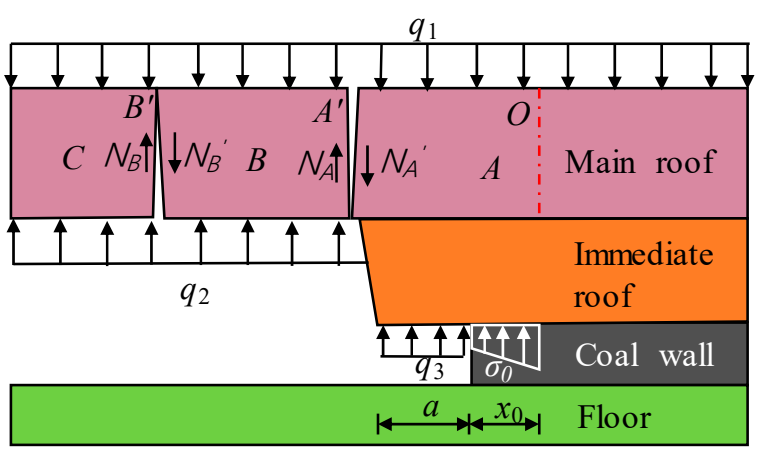

Figure 7. Theoretical model of side fracture in Gob.

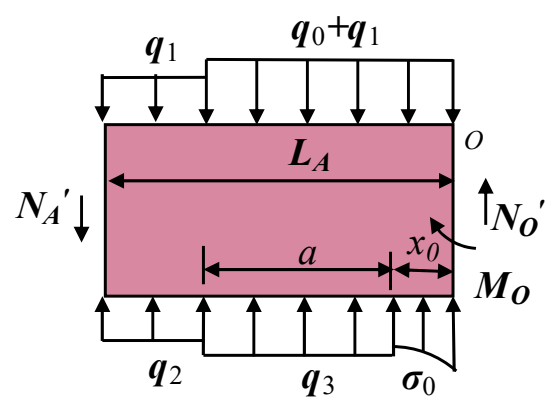

Figure 8. Free body diagram of key block A.

For block $\mathrm{B}$, as $\sum F_{y}=0, \sum M_{A^{\prime}}=0$,

$$
\begin{gathered}
q_{1} L_{\mathrm{B}}+N_{B}{ }^{\prime}-N_{A}-q_{2} L_{\mathrm{B}}=0, \\
N_{B}{ }^{\prime} L_{B}+q_{1} L_{B}{ }^{2} / 2-q_{2} L_{B}{ }^{2} / 2=0 .
\end{gathered}
$$

Simultaneously with the above equations, use:

$$
N_{A}=\left(q_{1}-q_{2}\right) L_{B} / 2
$$

As $\sum M_{O}=0$, then

$$
\begin{aligned}
& q_{0}\left(a+x_{0}\right)^{2} / 2+q_{1} L_{A}{ }^{2} / 2+N_{A}{ }^{\prime} L_{A}-q_{2}\left(L_{A}-a-x_{0}\right)^{2} / 2- \\
& P_{3}\left(a+2 x_{0}\right) / 2-\int_{0}^{x_{0}} \sigma_{0}\left(x_{0}-x\right) d_{x}-M_{O}=0
\end{aligned}
$$

Simultaneously with Equations (15) and (16), solve the temporary support strength in the roadway as:

$$
\begin{aligned}
P_{3}= & {\left[q_{0}\left(a+x_{0}\right)^{2}+q_{1} L_{A}^{2}+\left(q_{1}-q_{2}\right) L_{A} L_{B}-q_{2}\left(L_{A}-a-x_{0}\right)^{2}-\right.} \\
& \left.2 M_{O}-2 \int_{0}^{x_{0}} \sigma_{0}\left(x_{0}-x\right) d_{x}\right] /\left(a+2 x_{0}\right)
\end{aligned} .
$$

For convenience of simplification, we assume $L_{\mathrm{A}}=L_{\mathrm{B}}$; then $P_{1}-P_{3}=2\left(M_{0}-M_{\mathrm{A}}\right) /\left(a+2 x_{0}\right)$ is obtained. Meanwhile, the residual bending moment of the beam fracture, $M_{A}$, is much less than the bending moment occurring in the main roof, $M_{O}$. By comparing the theoretical models for the fracture of the main roof at the gob side and at the solid coal side and Equations (10) and (17), obviously, the temporary support strength in the roadway when the fracture site of the main roof is at the solid coal side is greater than that required at the gob side; namely $P_{1}>P_{3}$. The fracture occurrs above the roadway; one end of block $B$ is on the roadway, and there is no supporting force of the solid coal. Furthermore, comparing Equations (10) and (12), we know that the temporary support strength in the roadway when the fracture site of the main roof is at the coal side is greater than that required above the roadway; namely $P_{1}<P_{2}$. Therefore, it was concluded that when the temporary support residence 
in the roadway $P>P_{2}$, the fracture site of the main roof outside the roadway is at the gob side or the solid coal side; when $P<P_{2}$, the fracture of the main roof above the roadway leads to failure.

\section{Numerical Analysis of Roof Fracture Characteristics}

\subsection{Numerical Modeling}

As the lateral main roof may has three different fracture sites, the UDEC 2D model for the S1201-II mining face in Ningtiaota Coal Mine was established to simulate the movement of key rock blocks when the fracture position of main roof is on the side of coal wall, above the roadway and side of the gob.

The length and width of the model were 200 and $70 \mathrm{~m}$, respectively. The load applied on the upper boundary was considered equal to the maximum buried depth of $170 \mathrm{~m}$. The constitutive model of rock mass used was the Mohr-Coulomb model. The joint area contact-Coulomb slip model was used in the joint-constitutive model. The bottom boundary speed of the model was zero. And the horizontal direction of the left and right borders was limited to zero. The fracture sites in the main roof were $x_{0}=4 \mathrm{~m}$ away from the curved lane (the width of the solid coal-side stress limit equilibrium zone), right above the roadway, and $2 \mathrm{~m}$ away from the roadway (right above the slot top). The numerical model was as shown in Figure 9. Cable elements were used to simulate constant resistance anchor cable support. In addition, supporting structural elements were used to simulate temporary support in the roadway. Physical properties of the rock strata obtained from the drilling cores are presented in Table 1 [29].

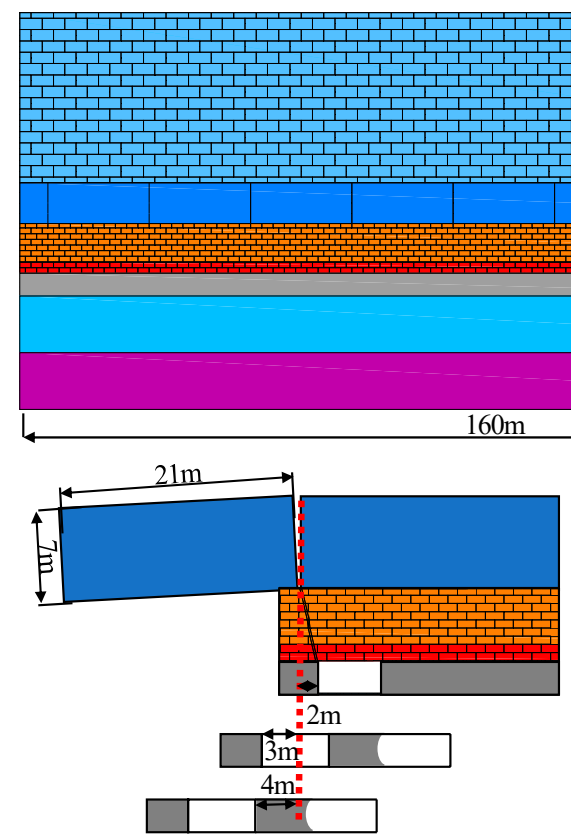

(b)

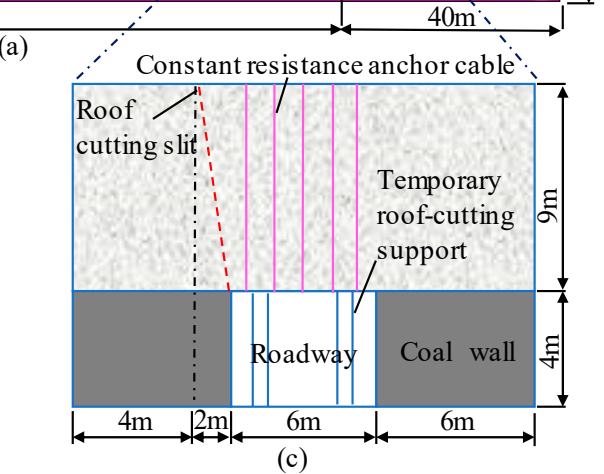

(c)

Figure 9. Model overview. (a). Model dimensions. (b) Spatial relationship between the location of the critical rock block fracture and the roadway. (c) Dimensions of the roadway. 
Table 1. Physical properties of the rock strata.

\begin{tabular}{ccccccc}
\hline Rock Strata & $\begin{array}{c}\text { Bulk Modulus } \\
\text { (GPa) }\end{array}$ & $\begin{array}{c}\text { Shear Elasticity } \\
\text { (GPa) }\end{array}$ & $\begin{array}{c}\text { Tensile Strength } \\
\text { (MPa) }\end{array}$ & $\begin{array}{c}\text { Cohesion } \\
\text { (MPa) }\end{array}$ & $\begin{array}{c}\text { Angle of Internal } \\
\text { Friction }(\mathbf{d e g})\end{array}$ & $\begin{array}{c}\text { Density } \\
\left(\mathbf{k g} / \mathbf{m}^{3}\right)\end{array}$ \\
\hline $\begin{array}{c}\text { Overlying } \\
\text { strata }\end{array}$ & 7.02 & 4.63 & 0.64 & 1.27 & 40.97 & 2310 \\
$\begin{array}{c}\text { Medium } \\
\text { sandstone }\end{array}$ & 5.46 & 4.27 & 0.58 & 1.12 & 41.33 & 2280 \\
$\begin{array}{c}\text { Siltstone } \\
\text { No. 2-2 coal }\end{array}$ & 4.81 & 3.92 & 0.39 & 0.92 & 38.45 & 2040 \\
$\quad$ seam & 3.95 & 3.22 & 0.36 & 0.85 & 39.69 & 1260 \\
$\begin{array}{c}\text { Siltstone } \\
\text { Fine }\end{array}$ & 10.23 & 8.33 & 1.22 & 2.05 & 40.81 & 2410 \\
sandstone & 3.78 & 3.08 & 0.85 & 1.75 & 38.42 & 2320 \\
\hline
\end{tabular}

\subsection{Results and Discussions of Numerical Simulation}

The caving forms of the main roof at different fracture sites are shown in Figure 10. When the main roof broke above the roadway, the extent of roadway deformation was greater than that in the other circumstances. When the main roof broke at the gob side, gangues mainly provided supporting forces against block $\mathrm{B}$ and the roadway was subjected to less pressure and the least deformation.
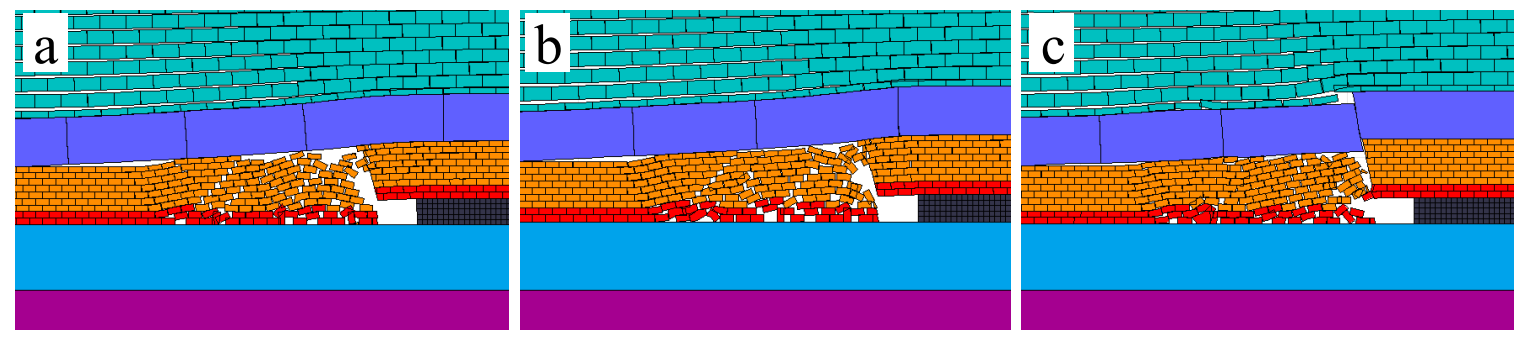

Figure 10. Rock mass collapse state of the main roof at different fracture locations. (a) Solid coal side. (b) Above the roadway. (c) Gob side.

A surveying line equal to the width of the roadway was provided on the surface above the roadway to obtain the extent of lateral roof deformation of the roadway at different fracture sites, as shown in Figure 11. The extent of roadway roof settling near the gob is obviously higher than that at any other site. The maximum roof settling values at the solid coal side, above the roadway, and at the gob side were $130 \mathrm{~mm}, 230 \mathrm{~mm}$, and $93 \mathrm{~mm}$, respectively. The roadway deformation and failure when the fracture of the main roof occurred above the roadway were more significant than those of any other circumstance. 


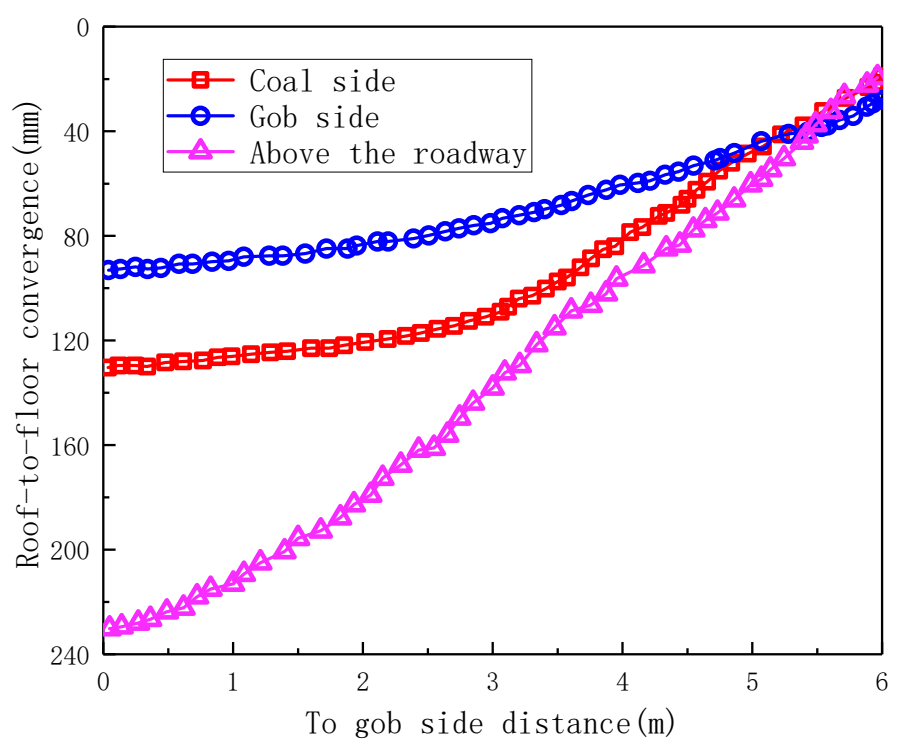

Figure 11. Roof migration of roadway with different fracture levels.

The variation curves of the settling observed in the roadway roof at the gob side, in the middle of the roadway, and at the curved coal side over time are shown in Figure 12a-c, respectively. The coal extraction from the mining face was completed; the deformation process of the main roof at the three fracture sites was divided into three stages-higher velocity in the early stage transitioning into a stabilized stage gradually. The deformation under the gob side fracture condition was concentrated in the early stage, and then slowly deformed until stabilized. The fracture process above the roadway was based on the deformation in former stages; the velocity of roof settling increased until the maximum values under the three fracture conditions were reached, respectively.

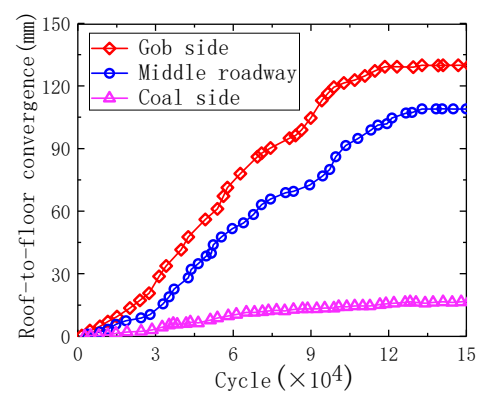

(a) Coal side

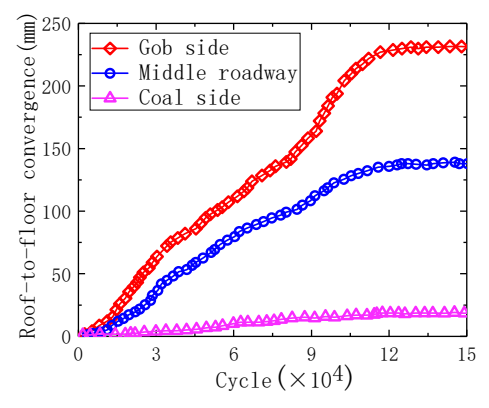

(b) Above the roadway

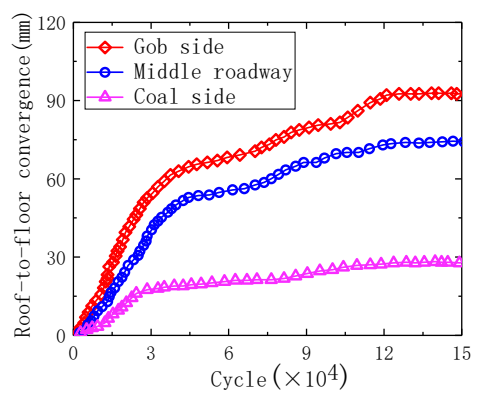

(c) Gob side

Figure 12. Deformation curve of roadway roof with different fracture positions.

\section{Engineering Applications}

\subsection{Formatting of Mathematical Components}

The coal seam extracted on the test face was the middle section of Yanan Formation of Jurassic Series. The coal seam thickness was 3.81-4.35 m, the average thickness was $4.11 \mathrm{~m}$, and the buried depth was $115-170 \mathrm{~m}$. The occurrence of the coal seam was stable and its dig angle was approximately horizontal. The dip length and strike length of the working face were 280 and $2344 \mathrm{~m}$, respectively. The position and the layout of the S1201-II working face are shown in Figure 13. 


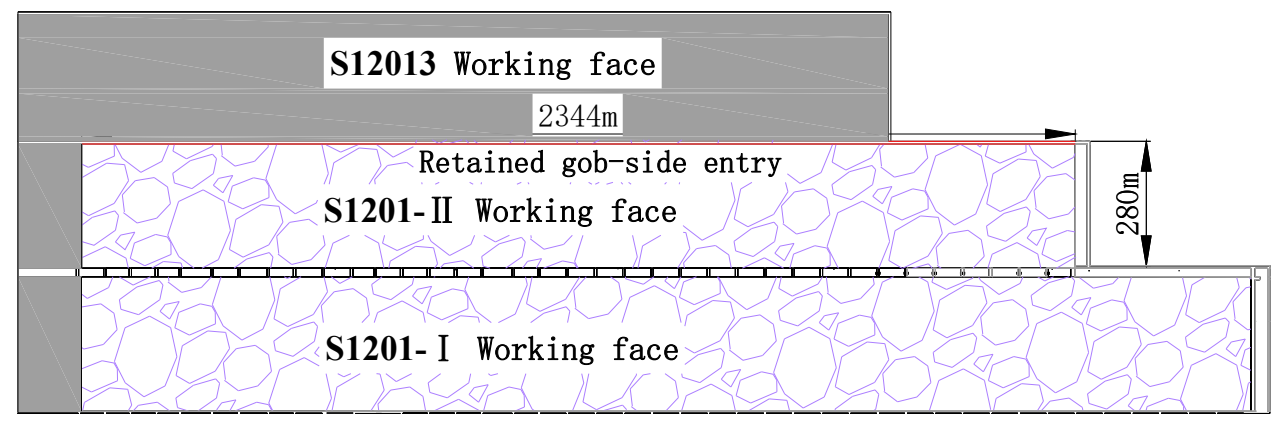

Figure 13. Working face layout of RFANM in Ningtiaota Coal Mine.

The main roof of the mining face was medium-grained sandstone with a thickness of 5.4-21.5 m, a medium sorting behavior, and large cross-bedding. The immediate roof was siltstone with a thickness of $0.78-4.05 \mathrm{~m}$. The immediate floor was siltstone with a thickness of 1.8-16.3 m, sandwiched and interbedded with a thin layer of fine-grained sandstone; the cleavage is shown. The main roof was fine-grained sandstone with a thickness of 3.2-19.6 m and wavy bedding.

\subsection{Roof Control and Roadway Formation Effect}

Generally, the probability that the main roof breaks above the roadway is smaller than those for the solid coal side and the gob side, but its threat to the roadway stability is often the highest. During the overburdening strata movement, the temporary support in the roadway should not only provide a large supporting force to resist the deformation, but also functions as "yielding" to deal with the "given deformation" of the main roof. Cutting roof support is the main temporary support for the roadway. The support strength of roof-cutting support has an important influence on the fracture position on a basic roof and plays an important role in roadway stability.

RFANM follows the mining face closely to provide active support against the roadway roof with constant resistance and a large deformation anchor cable. The constant-resistance anchor cable is mounted before the surrounding rock of the roadway becomes deformed, so as to avoid the bed separation from the roadway roof. The support provided by the constant-resistance anchor cable enhances the anti-breaking capacity of the equivalent immediate roof, so that the fracture site of the lower roof tends to approach the gob side, which is beneficial to avoid the fracture of the main roof above the roadway.

By designing the slotting parameters, the gangues in the gob can achieve better effects of cracking-expansion and filling, which alleviate the impact of the intense motion of key blocks on the stability of the surrounding rock. Subject to the supporting force of the gangues in the gob and the temporary support in the roadway, the fracture line of the main roof shifts to the depth of the solid coal side or to the gob. This is significant for the stabilization of the surrounding rock of the roadway.

The variation curve of the roof and floor displacement with the advance of the mining face, as shown in Figure 14, was drawn by monitoring the roof displacement and selecting the typical measurement points with timely distribution and the longest monitoring duration at $930 \mathrm{~m}$ from the open-off cut. The variation of the roof and floor displacement was similar to that of the fracture of the main roof at the solid coal side and the gob side. The maximum roof and floor displacement at the gob side was $128.1 \mathrm{~mm}$, which was approximately equal to the maximum deformation at the solid coal side. It was initially concluded that the main roof in the formation section broke at the solid coal side. 


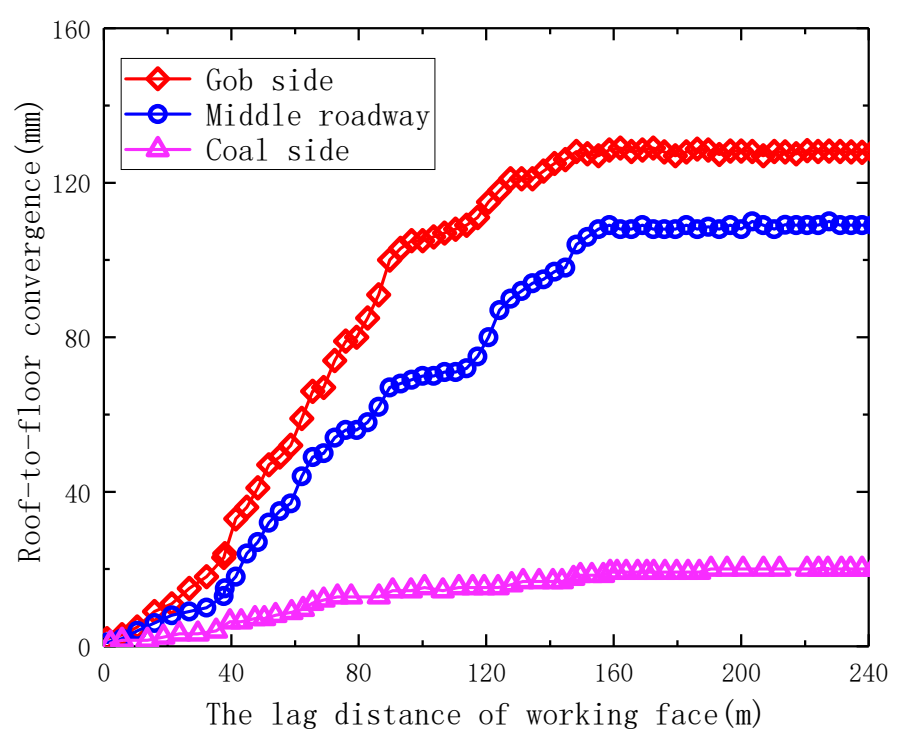

Figure 14. Roof migration of a roadway with different fracture levels.

The roadway roof was drilled and peeped using a mine borescope. Figure 15 shows the peeping result at $930 \mathrm{~m}$ from the open-off cut and $10 \mathrm{~cm}$ from the coal wall with the drilling angles of $60^{\circ}$ and $70^{\circ}$, respectively. It was observed that the peeping result of the fracture site of the main roof in this entry retaining section $3.6 \mathrm{~m}$ from the coal wall was basically consistent with the field displacement monitoring and simulation result. The field roadway formation effect is shown in Figure 16.

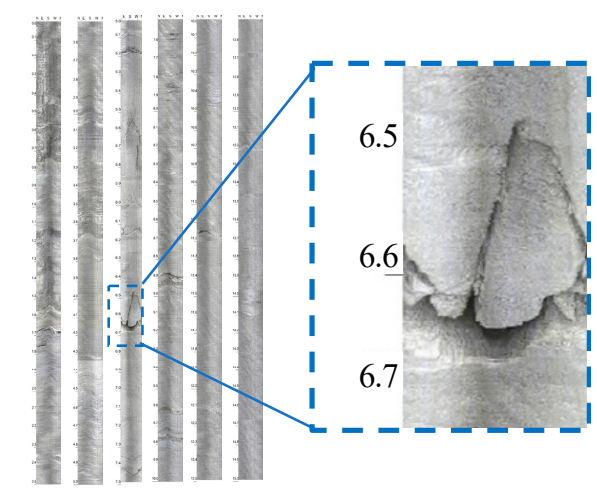

(a) Drilling angle is $60^{\circ}$

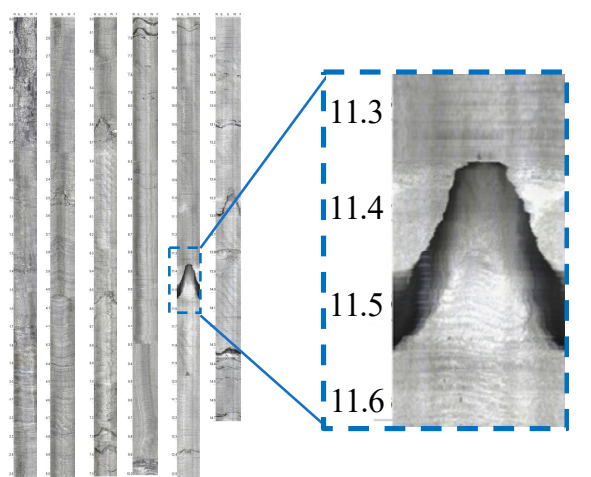

(b) Drilling angle is $70^{\circ}$

Figure 15. Drilling peep results. 


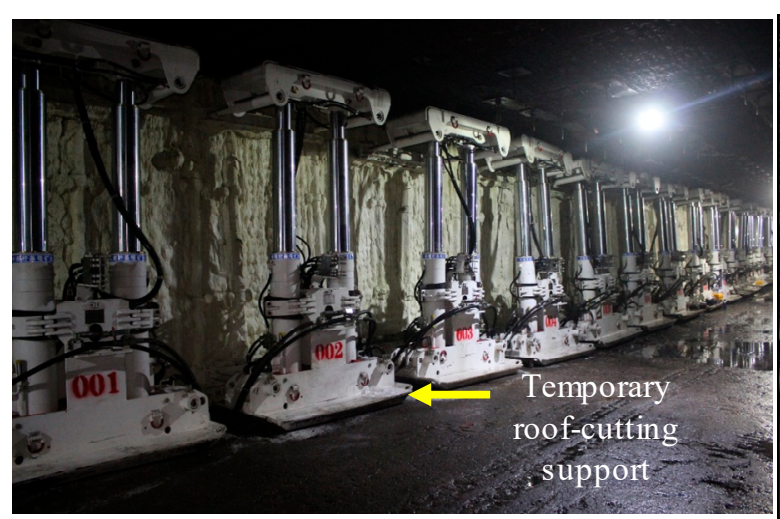

(a) Temporary roof-cutting support

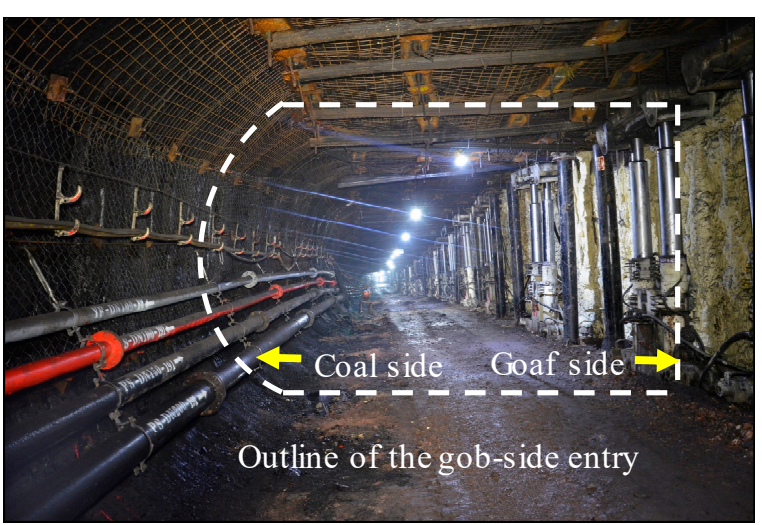

(b) Outline of the gob-side entry

Figure 16. Field lane effect.

\section{Conclusions}

In this study, the theoretical models for different fracture sites of the main roof were established, the equations for temporary support strength in the roadway when the main roof was at three fracture sites were derived, respectively, the critical value for the temporary support strength in the roadway was thus obtained, which offered theoretical evidence for the support design in RFANM.

We discovered that the fracture observed in the main roof at different sites was closely related to the stability of the surrounding rock of the roadway. The required temporary support in the roadway varied from site to site. When the main roof broke above the roadway, the temporary support strength required for the roadway to maintain stability was the largest. Thus, during the mining working in RFANM, the main roof was prevented from breaking above the roadway.

The deformation of key blocks at three fracture sites were simulated using the UDEC. The comparison of displacement variation of the roadway roof indicates that the roadway deformation is smaller when the main roof fractures at the solid coal side and the gob side.

The industrial test for RFANM was conducted on the S1201-IImining face, deformation of the roadway can be effectively controlled by using roof cutting support, constant resistance anchor cable support, resulting in good formation effect, better social and economic benefits.

Author Contributions: J.Y. and Y.W. conceived and designed the research; H.W. and B.L. performed the numerical simulation and field test; S.H. and Y.C. analyzed the data; H.W. wrote the paper.

Funding: This research was funded by the National Key Research and Development Program (grant numbers 2018YFC0603705 and 2016YFC0600901), the National Natural Science Foundation of China (grant numbers 51674265 and 51904207) and Yue Qi outstanding scholar award program of China University of Mining and Technology, Beijing.

Conflicts of Interest: The authors declare no conflict of interest.

\section{References}

1. Arya, S.; Sottile, J.; Novak, T. Development of a flooded-bed scrubber for removing coal dust at a longwall mining section. Saf. Sci. 2018, 110, 204-213. [CrossRef]

2. Bai, Q.; Tu, S. A General Review on Longwall Mining-Induced Fractures in Near-Face Regions. Geofluids 2019, 2019, 1-22. [CrossRef]

3. Wang, Q.; He, M.; Yang, J.; Gao, H.; Jiang, B.; Yu, H. Study of a no-pillar mining technique with automatically formed gob-side entry retaining for longwall mining in coal mines. Int. J. Rock Mech. Min. 2018, 110, 1-8. [CrossRef]

4. Adhikary, D.; Khanal, M.; Jayasundara, C.; Balusu, R. Deficiencies in 2D Simulation: A Comparative Study of 2D Versus 3D Simulation of Multi-seam Longwall Mining. Rock Mech. Rock Eng. 2016, 49, 2181-2185. [CrossRef] 
5. Barbato, J.; Hebblewhite, B.; Mitra, R.; Mills, K. Prediction of horizontal movement and strain at the surface due to longwall coal mining. Int. J. Rock Mech. Min. 2016, 84, 105-118. [CrossRef]

6. Yang, X.; Wang, E.; Wang, Y.; Gao, Y.; Wang, P. A Study of the Large Deformation Mechanism and Control Techniques for Deep Soft Rock Roadways. Sustainability 2018, 10, 1100. [CrossRef]

7. Ghosh, G.K.; Sivakumar, C. Application of underground microseismic monitoring for ground failure and secure longwall coal mining operation: A case study in an Indian mine. J. Appl. Geophys. 2018, 150, 21-39. [CrossRef]

8. Wang, M.; Bai, J.; Li, W.; Wang, X.; Cao, S. Failure mechanism and control of deep gob-side entry. Arab. J. Geosci. 2015, 8, 9117-9131. [CrossRef]

9. Yang, J.; He, M.; Cao, C. Design principles and key technologies of gob side entry retaining by roof pre-fracturing. TUNN UNDERGR SP TECH 2019, 90, 309-318. [CrossRef]

10. Qian, D.; Zhang, N.; Shimada, H.; Wang, C.; Sasaoka, T.; Zhang, N. Stability of goaf-side entry driving in 800-m-deep island longwall coal face in underground coal mine. Arab J. Geosci 2016, 9, 82. [CrossRef]

11. Wang, Y.; Gao, Y.; Wang, E.; He, M.; Yang, J. Roof Deformation Characteristics and Preventive Techniques Using a Novel Non-Pillar Mining Method of Gob-Side Entry Retaining by Roof Cutting. Energies 2018, 11, 627. [CrossRef]

12. Gao, Y.; Liu, D.; Zhang, X.; He, M. Analysis and Optimization of Entry Stability in Underground Longwall Mining. Sustainability 2017, 9, 2079. [CrossRef]

13. Qian, M.; Miao, X.; He, F. Analysis of key block in the structure of voussoir beam in longwall mining. J. China Coal Soc. 1994, 19, 557-563.

14. Poulsen, B.A. Coal pillar load calculation by pressure arch theory and near field extraction ratio. Int. J. Rock Mech. Min. 2010, 47, 1158-1165. [CrossRef]

15. Han, C.; Zhang, N.; Li, B.; Si, G.; Zheng, X. Pressure relief and structure stability mechanism of hard roof for gob-side entry retaining. J. Cent. South Univ. 2015, 22, 4445-4455. [CrossRef]

16. Li, X.; Ju, M.; Yao, Q.; Zhou, J.; Chong, Z. Numerical Investigation of the Effect of the Location of Critical Rock Block Fracture on Crack Evolution in a Gob-side Filling Wall. Rock Mech. Rock Eng. 2016, 49, 1041-1058. [CrossRef]

17. Luan, H.; Jiang, Y.; Zhou, L.; Lin, H. Stability Control and Quick Retaining Technology of Gob-Side Entry: A Case Study. Adv. Civ. Eng. 2018, 2018,1-13. [CrossRef]

18. Ma, X.; He, M.; Wang, J.; Gao, Y.; Zhu, D.; Liu, Y. Mine Strata Pressure Characteristics and Mechanisms in Gob-Side Entry Retention by Roof Cutting under Medium-Thick Coal Seam and Compound Roof Conditions. Energies 2018, 11, 2539. [CrossRef]

19. Ma, Z.; Wang, J.; He, M.; Gao, Y.; Hu, J.; Wang, Q. Key Technologies and Application Test of an Innovative Noncoal Pillar Mining Approach: A Case Study. Energies 2018, 11, 2853. [CrossRef]

20. Ma, X.; He, M.; Sun, J.; Wang, H.; Liu, X.; Zhen, E. Neural Network of Roof Cutting Blasting Parameters Based on Mines with Different Roof Conditions. Energies 2018, 11, 3468. [CrossRef]

21. Zhen, E.; Gao, Y.; Wang, Y.; Wang, S. Comparative Study on Two Types of Nonpillar Mining Techniques by Roof Cutting and by Filling Artificial Materials. Adv. Civ. Eng. 2019, 2019, 5267240. [CrossRef]

22. Guo, Z.; Zhang, L.; Ma, Z.; Zhong, F.; Yu, J.; Wang, S. Numerical Investigation of the Influence of Roof Fracturing Angle on the Stability of Gob-Side Entry Subjected to Dynamic Loading. Shock Vib. 2019, 2019, 1434135. [CrossRef]

23. He, M.; Zhu, G.; Guo, Z. Longwall mining "cutting cantilever beam theory" and 110 mining method in China-The third mining science innovation. J. Rock Mech. Geotech. Eng. 2015, 7, 483-492. [CrossRef]

24. He, M.; Gong, W.; Wang, J.; Qi, P.; Tao, Z.; Du, S.; Peng, Y. Development of a novel energy-absorbing bolt with extraordinarily large elongation and constant resistance. Int. J. Rock Mech. Min. 2014, 67, 29-42. [CrossRef]

25. Zhang, N.; Zhang, N.; Han, C.; Qian, D.; Xue, F. Borehole stress monitoring analysis on advanced abutment pressure induced by Longwall Mining. Arab. J. Geosci. 2014, 7, 457-463. [CrossRef]

26. Han, C.; Zhang, N.; Ran, Z.; Gao, R.; Yang, H. Superposed disturbance mechanism of sequential overlying strata collapse for gob-side entry retaining and corresponding control strategies. J. Cent. South Univ. 2018, 25, 2258-2271. [CrossRef]

27. David, K.; Timms, W.A.; Barbour, S.L.; Mitra, R. Tracking changes in the specific storage of overburden rock during longwall coal mining. J. Hydrol. 2017, 553, 304-320. [CrossRef] 
28. Hou, C. Stress in in-seam roadway sides and limit equilibrium zone. J. China Coal Soc. 1989, 14, 21-29.

29. Manchao, H.; Yajun, W.; Jun, Y.; Peng, Z.; Qing, G.; Yubing, G. Comparative analysis on stress field distributions in roof cutting non-pillar mining method and conventional mining method. J. China Coal Soc. 2018, 43, 626-637. 